\title{
THE ROLE OF GEOPHYSICAL ERT METHOD TO EVALUATE THE LEAKPROOFNESS OF DIAPRAGM WALL OF DEEP FOUNDATION TRENCHES ON THE EXAMPLE OF THE CONSTRUCTION OF RETAIL AND OFFICE COMPLEX IN LUBLIN, POLAND
}

\author{
Grzegorz Pacanowski ${ }^{1}$, Pawel Czarniak ${ }^{1}$, Anna Bąkowska², Radosław Mieszkowski ${ }^{2}$, Fabian Welc ${ }^{3}$ \\ ${ }^{1}$ Polish Geological Institute - National Research Institute, Rakowiecka 4, 00-975 Warsaw, Poland, \\ e-mails: grzegorz.pacanowski@pgi.gov.pl,pawel.czarniak@pgi.gov.pl \\ ${ }^{2}$ University of Warsaw, Faculty of Geology, Institute of Hydrogeology and Engineering Geology, \\ Żwirki i Wigury93,02-089 Warsaw,Poland, e-mail: anna.bakowska@uw.edu.pl,r.mieszkowski@uw.edu.pl \\ ${ }^{3}$ Instytut Archeologii Uniwersytet Kardynała Stefana Wyszyńskiego, ul. Woycickiego 1/3, no. 23, \\ 01-938 Warszawa, Poland, e-mail:f.welc@uksw.edu.pl.
}

\begin{abstract}
This paper addresses the problem of assessing the leakproofness of the bottom of a deep foundation trench, secured by cavity wall, using geophysical methods of electrical resistivity tomography. The study was conducted on a large construction project in Lublin, in a place where there are complicated soil-water conditions: the groundwater level is above the proposed depth of foundation trench, the subsoil is heterogeneous, and there are karsted and weathered carbonate sediments with confined aquifer below the bottom of the trench. A hydraulic fracture occurred at the bottom of the trench during the engineering works, which caused the water flow into the trench. In order to recognize the soil-water conditions the first stage of geophysical measurements of electrical resistivity tomography (ERT) was made. The applied methodology allowed to determine the extent of the hydraulic fracture zone within the bottom of foundation trench. In order to assess the leakproofness of Diaphragm Wall the geophysical ERT measurements were repeated (stage 2) A clear reduction in the value of the electrical resistivity of soils in the area of hydraulic fracture was caused by clay injection. The results of ERT measurements are discussed and graphically presented.
\end{abstract}

Key words: Electrical Resistivity Tomography (ERT), hydraulic fracture, clay injection, foundation trench, complicated soil-water conditions.

Manuscript received 5 May 2014, accepted 6 November 2014

\section{INTRODUCTION}

Geophysical methods began to be used to solve geotechnical problems in the " 60 s and ' 70 s of the twentieth century (Keller \& Frischknecht 1966, Bogoslovsky \& Ogilvy 1977), mainly the seismic method and the electrical resistivity method. Currently non-invasive geophysical surveys are performed to identify soil-water conditions at the design stage of any large construction project. Geophysical investigation can determine or elaborate on: geological structure (Keller \& Frischknecht, 1966), elastic soils parameters and degree of consolidation of soils (Foti \& Lancellotta, 2003), identification of buried technical infrastructure (Jol et al. 2009), shallow cavities in rock mass (Martínez-Pagán et al., 2013), monitoring of the environment (Sharma, 2002), hydrogeological conditions (Kirsch, 2009; Brunet et al., 2010), risk of landslides processes (Göktürkler et al., 2008; Hack, 2000), hazards of mining areas (Chambers et al., 2007) and many others (e.g. Kowalczyk, Mieszkowski, 2011 and Barski, Mieszkowski, 2014).

In the case of construction projects that are, or will be sited in complicated soil-water conditions (e.g. shallow groundwater level or the impact of soils of low bearing capacity) geophysical monitoring is conducted. Its purpose is to control the soils before and after stabilization works, such as the seal (injection) of clayey slurry or cementing. Geophysical investigations on structures of this type are described, in the works of Cardarelli et al. (2007), Farooq et al. (2007), Ramirez et al. (1993), Daily \& Ramirez (2000), Santarato et al. (2011) and Slater et al. (2000).

The paper focuses on the presentation of the methodology and results of geophysical ERT method used to deter- 


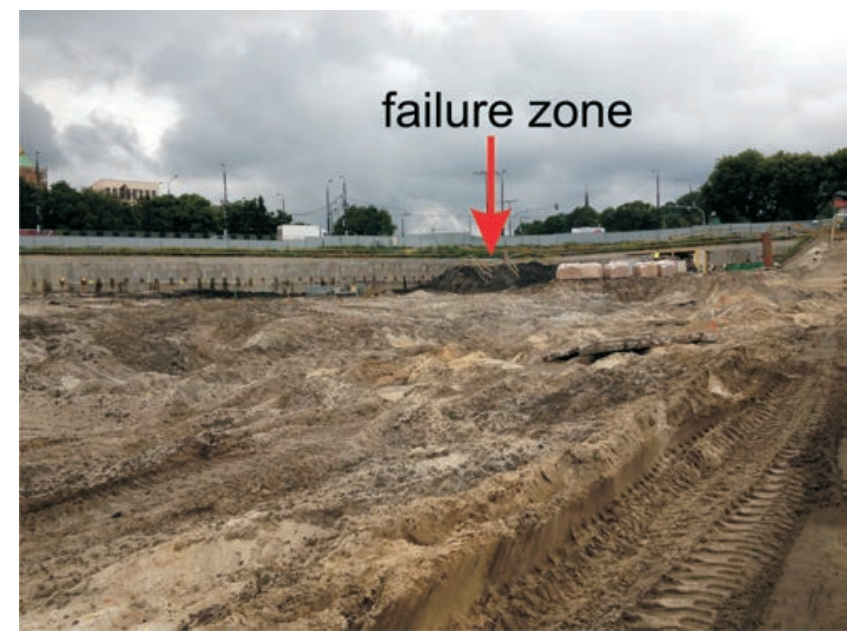

Fig. 1. View of the NW part of the foundation trench.

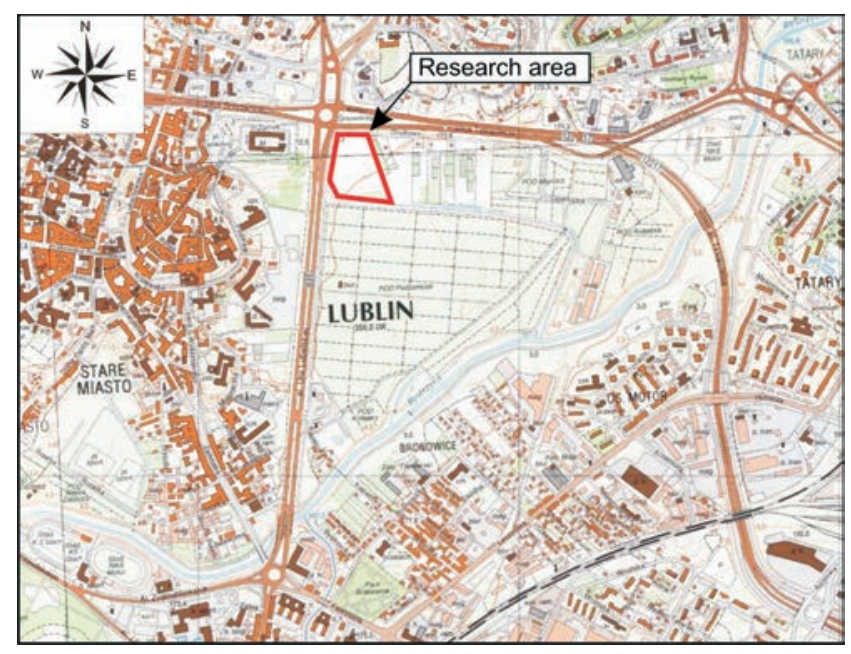

Fig. 2. Location of the ERT geophysical research area.

mine the hydraulic fracture zone at the bottom of the selected foundation trench and to control the leakproofness of soils in the bottom of the trench after the sealed works.

\section{CASE-HISTORY}

In 2012, giant office and service complex started to be built in Lublin (south-eastern part of Poland). The area of deep excavation was approximately 2.5 ha (Fig. 1). Location of the investment is shown in Fig. 2.

Level of the foundation plate was designed at a depth of approximately $10 \mathrm{~m}$ below ground surface (161.2 $\mathrm{m}$ above the sea level). The trench was protected by Diaphragm Wall. At the stage of designing the construction a wide range of geotechnical and geological measurements were conducted to identify the geological structure and to determine the physical and mechanical parameters of soils: drillings, static probing (CPT) and basic laboratory tests of soil samples collected during drilling. The interpretation of the geological structure was shown in the form of geological cross-sections (Fig. 4) the unexplored rock and soil mass between the boreholes was interpolated. On the basis of this interpretation it was con-

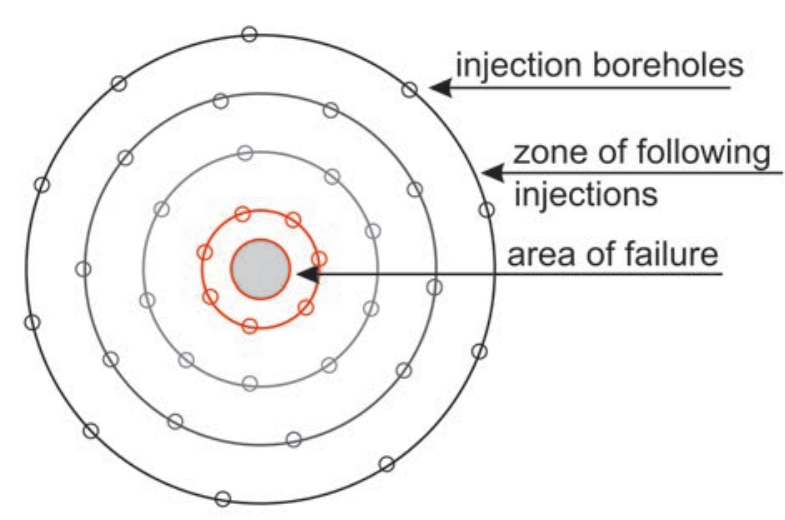

Fig. 3. Schematic layout of injection holes around the damaged piezometer (area of failure).

cluded that the deepening of the foundation trench and the performance of the bottom plate will not encounter any environmental difficulties. In the spring 2013, while dredging in the north-western part of the excavation, the old previously unidentified piezometer was damaged by the excavator. This piezometer was used to monitor the fissure water level in Cretaceous sediments. Fissure water level in the Cretaceous sediments was under considerable piezometric pressure: it is level was drilled ca at $155 \mathrm{~m}$ above sea level, while stabilized at ca 166 meters above sea level and about $5 \mathrm{~m}$ above the projected bottom of the foundation trench. As a result of failure the water rapidly began to flood the trench. Damaged piezometer was sealed quickly, then large embankment was piled high around it to secure the bottom of the trench from expanding hydraulic fracture zone and continued flooding. This action has stopped the flow of water for a period of time but also stopped construction works for several months.

It was decided that the area of failure will be sealed by diaphragm wall made of clayey slurry injections. Schematic layout of injection holes around the damaged piezometer is shown in Fig. 3. In order to determine the extent of hydraulic fracture zone it was decided to conduct geophysical measurements of system 2D and quasi 3D of electrical resistivity tomography (study of quasi 3D results were generated from 2D lines). After clayey slurry injections whithin these zones the construction works have been completed without major problems in 2013.

\section{THE GEOLOGY}

The geology of the investment area was identified by drilling and static probing to a depth of approximately $24 \mathrm{~m}$ (to $148.2 \mathrm{~m}$ above sea level). Drilling and probing (in the total amount of 23) was located mainly around the perimeter of the projected diaphragm walls (Fig. 4). The geological profile is (from top): anthropogenic embankments (of $4 \mathrm{~m}$ thickness), Quaternary organic soils (of 4 m thickness), Quaternary river sands interbedded by alluvial soils (silty clay and silt of a thickness from 3 to $6 \mathrm{~m}$ ), Neogene clays and silts (of 9-10 m thickness) and Cretaceous carbonate rocks. The roof 


\section{Simplified geological cross-section of the north wall of the faundation trench}
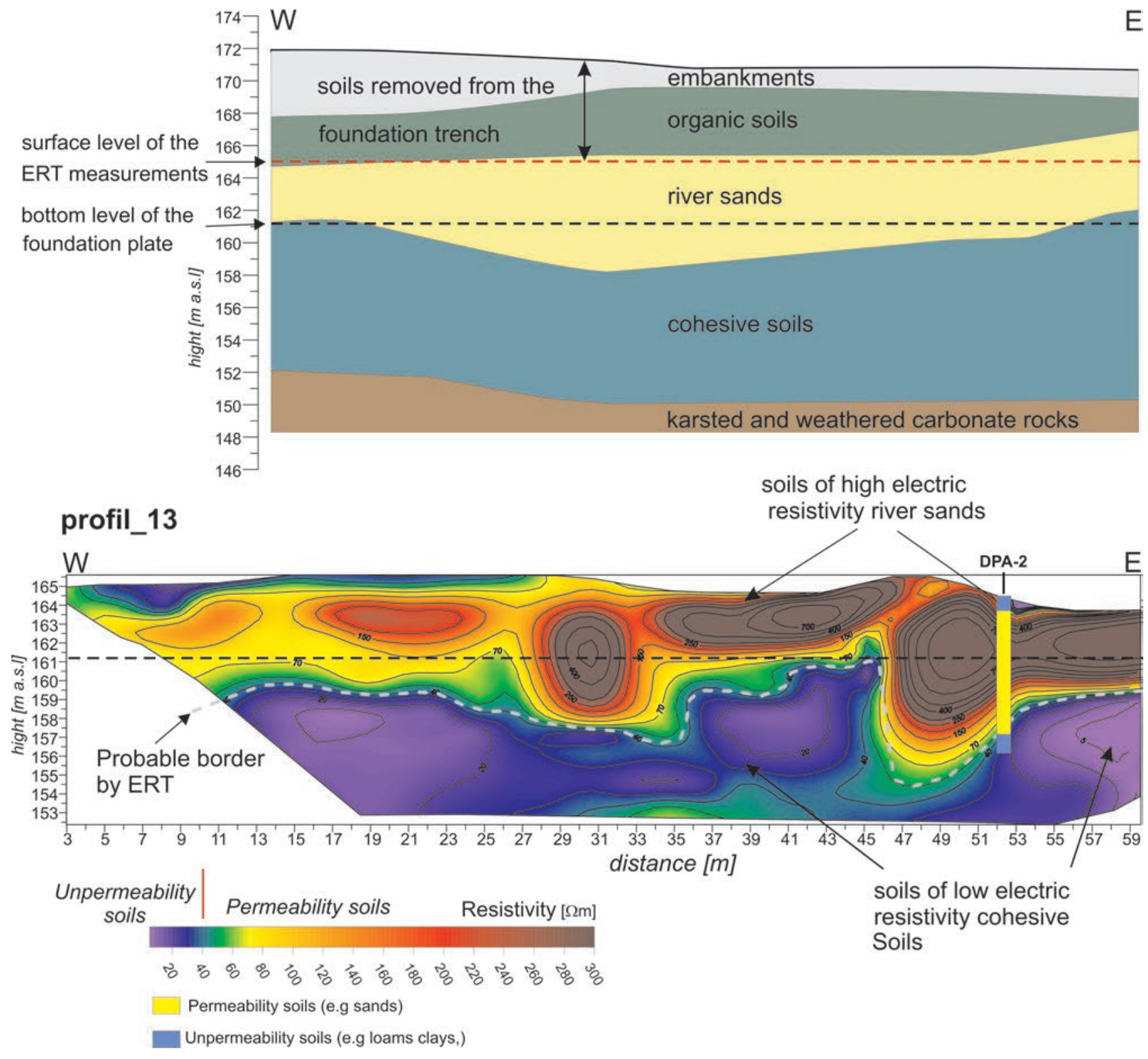

Fig. 4. Simplified geological cross-section in the area of failure (above) and geophysical picture of ERT measurement (below). Geophysical investigations were performed after removing the top layer of embankments and organic soils.

of Cretaceous deposits is at depth ca $25 \mathrm{~m}$ below ground surface (ca $155 \mathrm{~m}$ above sea level).

The floor of the Cretaceous rocks wasn't reached.

There are two aquifers in this profile:

- first groundwater level, unconfined aquifer, in Quaternary river sands, at a depth of 7.5-8 $\mathrm{m}$ (approximately $164 \mathrm{~m}$ above sea level),

- second groundwater level, confined aquifer, in the Cretaceous rocks, level occurred at a depth of about $20-22 \mathrm{~m}$ (150-152 $\mathrm{m}$ above sea level), while stabilized at a depth of 5-6 $\mathrm{m}$ (166 $\mathrm{m}$ above sea level)

Simplified geological cross-section in the area of failure is presented in Fig. 4. It should be noted that the location of geological boundaries is almost horizontal, and the different geological layers have a similar thickness. There were no erosion cuts detected.

\section{THE METHODOLOGY OF ERT MEASUREMENTS}

Geophysical measurements of electrical resistivity tomography (ERT) were conducted within the foundation trench. Electrical resistivity tomography method was developed in the late twentieth century and is widely described by many researchers, for example by Griffiths \& Barker (1993) and Loke'a (2012). This method was chosen because of the expected contrasts in the electrical resistivity of soils.

Measurements were carried out in two stages:

- Stage 1: Extent of hydraulic fracture zone within the bottom of the foundation trench was specified.

- Stage 2: Leakproofness of diaphragm wall (clayey slurry injections) made in the bottom of the trench (on the basis of step 1) was specified. 


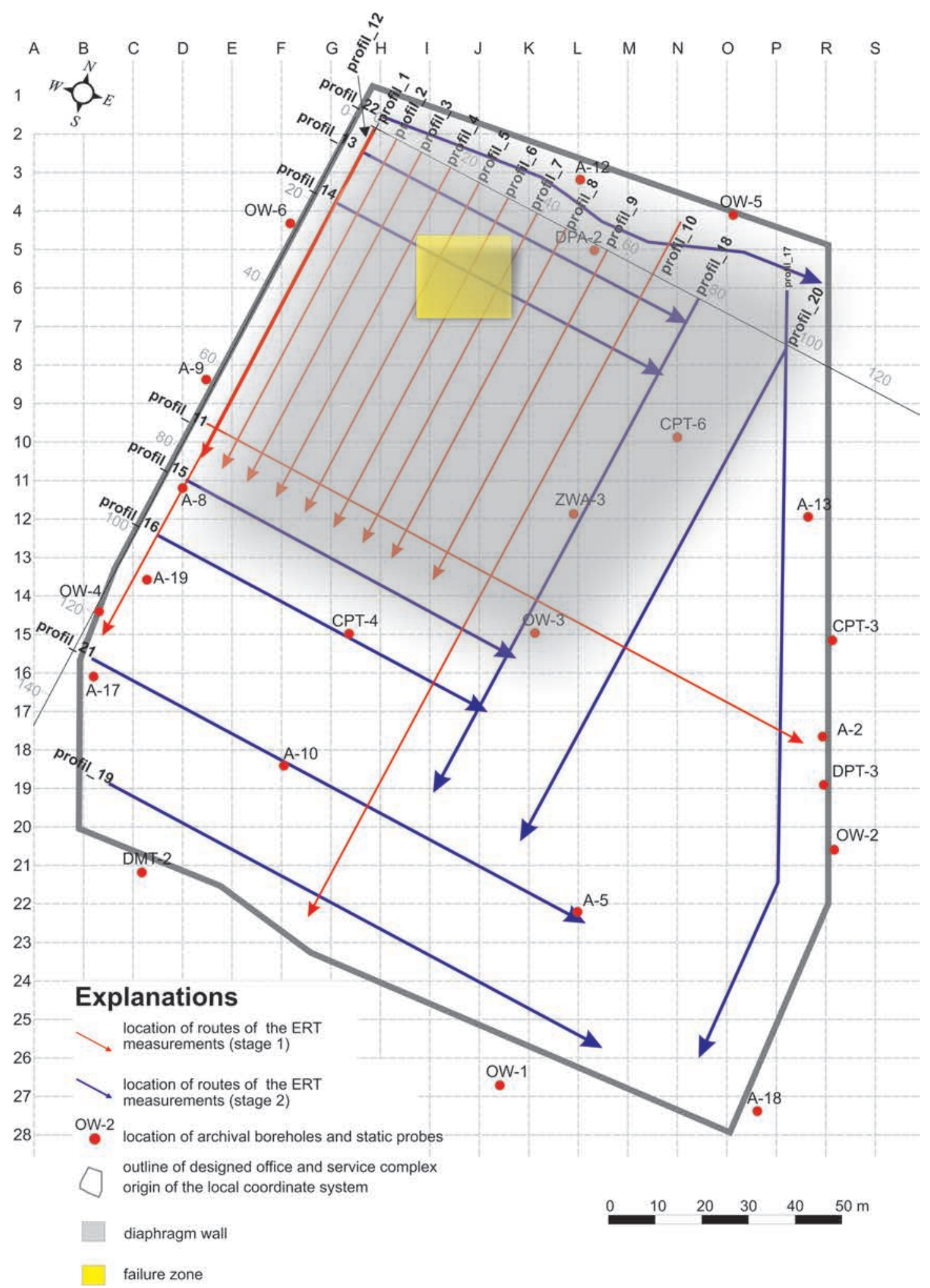

Fig. 5. Documentary map of ERT measurements.

The location of measurement profiles are shown in Fig. 5. The fracture zone is situated in the NW part of the trench (Fig. 5).

The measurements were made using Terameter LS apparatus (manufactured by ABEM, Sweden). The dipole-dipole array was used. This array was chosen for two reasons: firstly it gives high density of measurement points, secondly it allows the use of multi-channel measurements. Relatively short time of measurements was very important. In the hydraulic fracture zone (north-western part of the trench) there was $2 \mathrm{~m}$ interval between electrodes and a length of measuring profiles was limited by the length of the foundation trench to the $80 \mathrm{~m}$. Thus the depth of recognition of distribution of electrical resistivity in the subsoil was up to approximately $13-14 \mathrm{~m}$. 

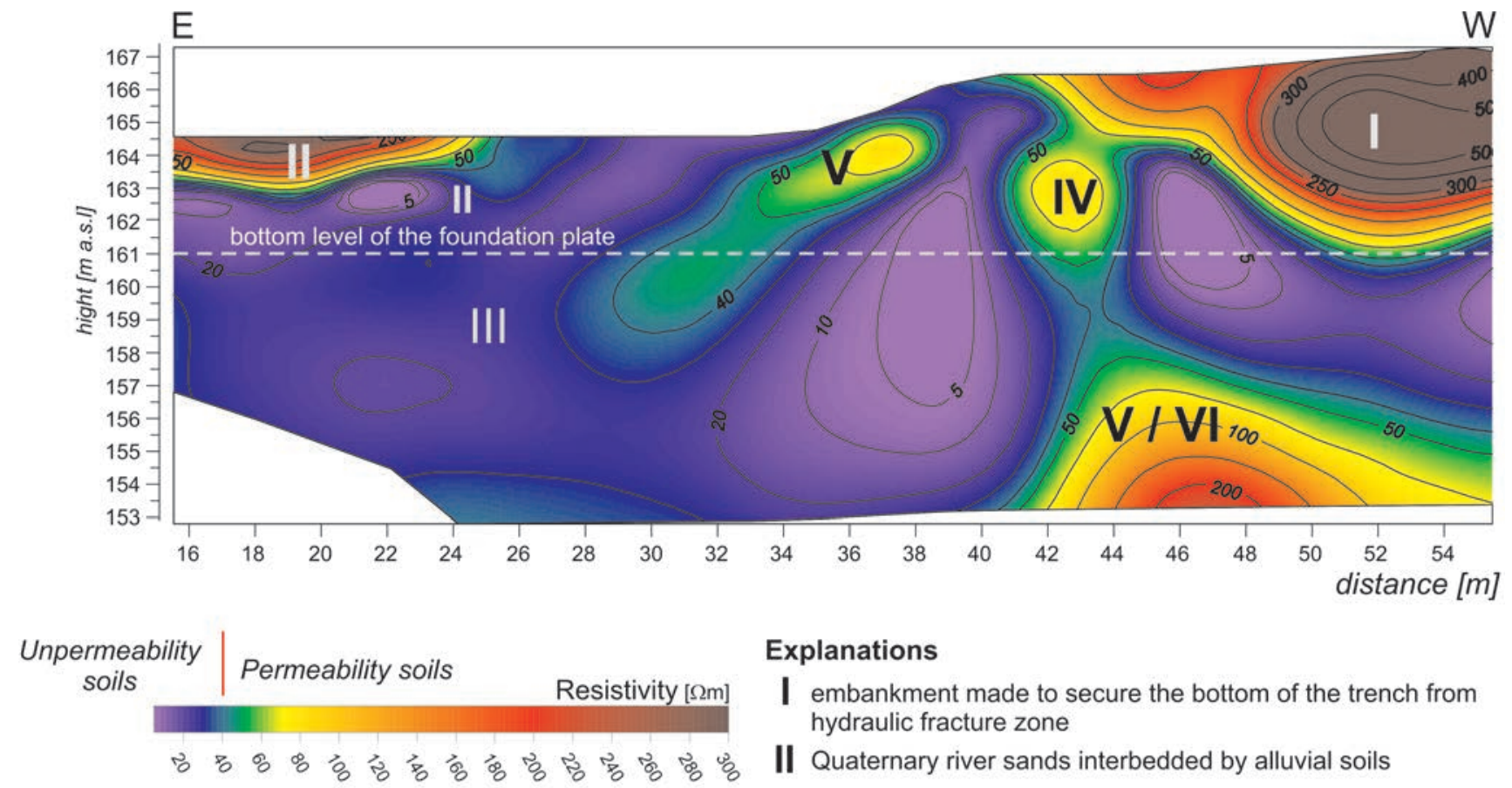

\section{Explanations}

I embankment made to secure the bottom of the trench from hydraulic fracture zone

II Quaternary river sands interbedded by alluvial soils

III Neogene cohesive soils - Neogene clays and silts

IV hydraulic fracture zone

V zone of electric resistivity increased (layer of saturated sands propable)

VI zone of electric resistivity increased (karsted rocks)

Fig. 6. Electrical resistivity cross-section- stage 1, profile 14 .
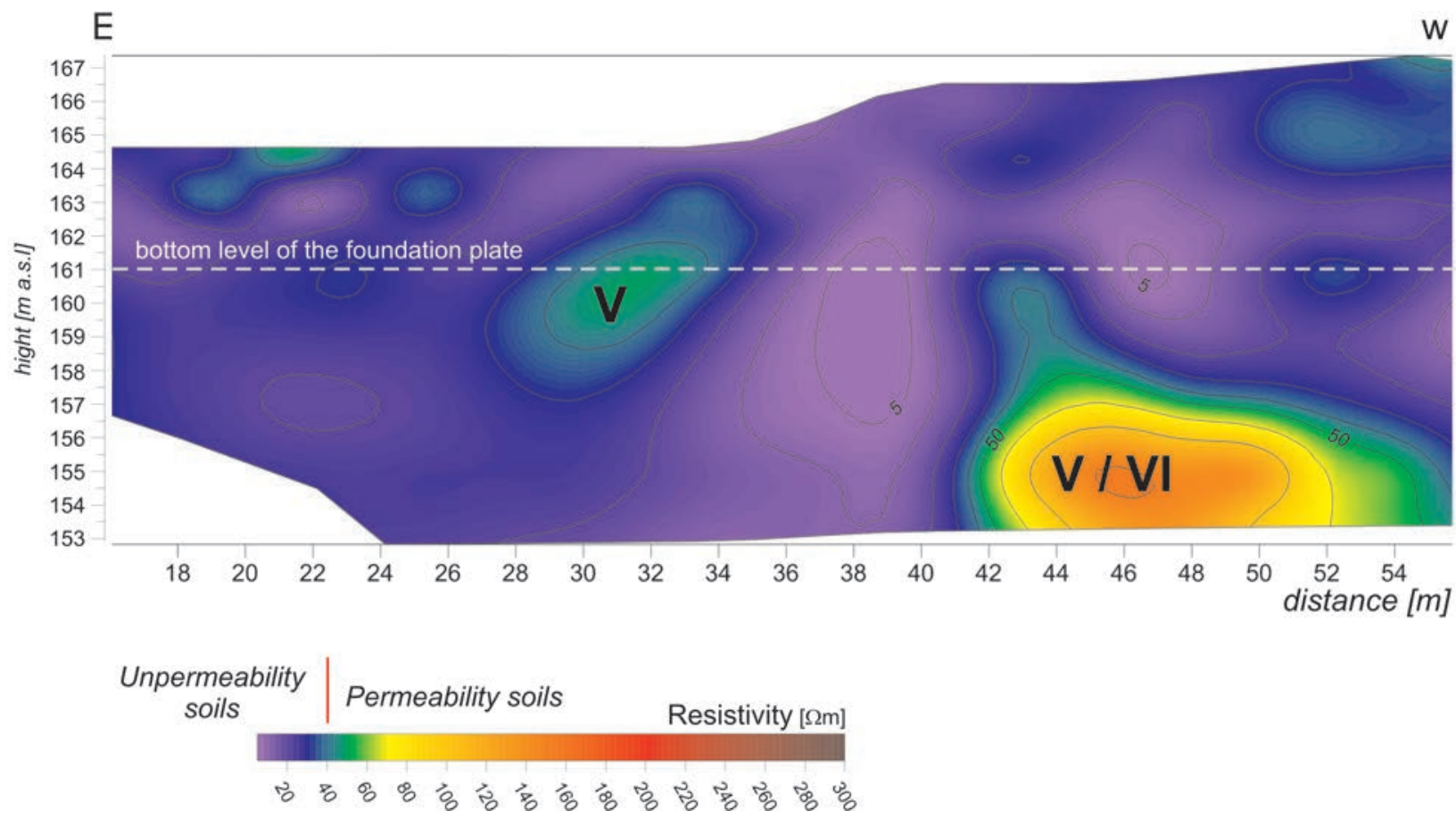

Fig. 7. Electrical resistivity cross-section- stage 2, profile 14 (Explanations as Fig. 6).

Additional measurements were carried out in the entire trench area to develop a map of the roof of Neogene cohesive deposits. This soil layer was particularly important, because it protects the trench from the confined aquifer. Additional
ERT profiles were also made using dipole-dipole array, but the interval of the electrodes was increased to 3-4 $\mathrm{m}$ which gives a slightly greater depth of prospecting. 

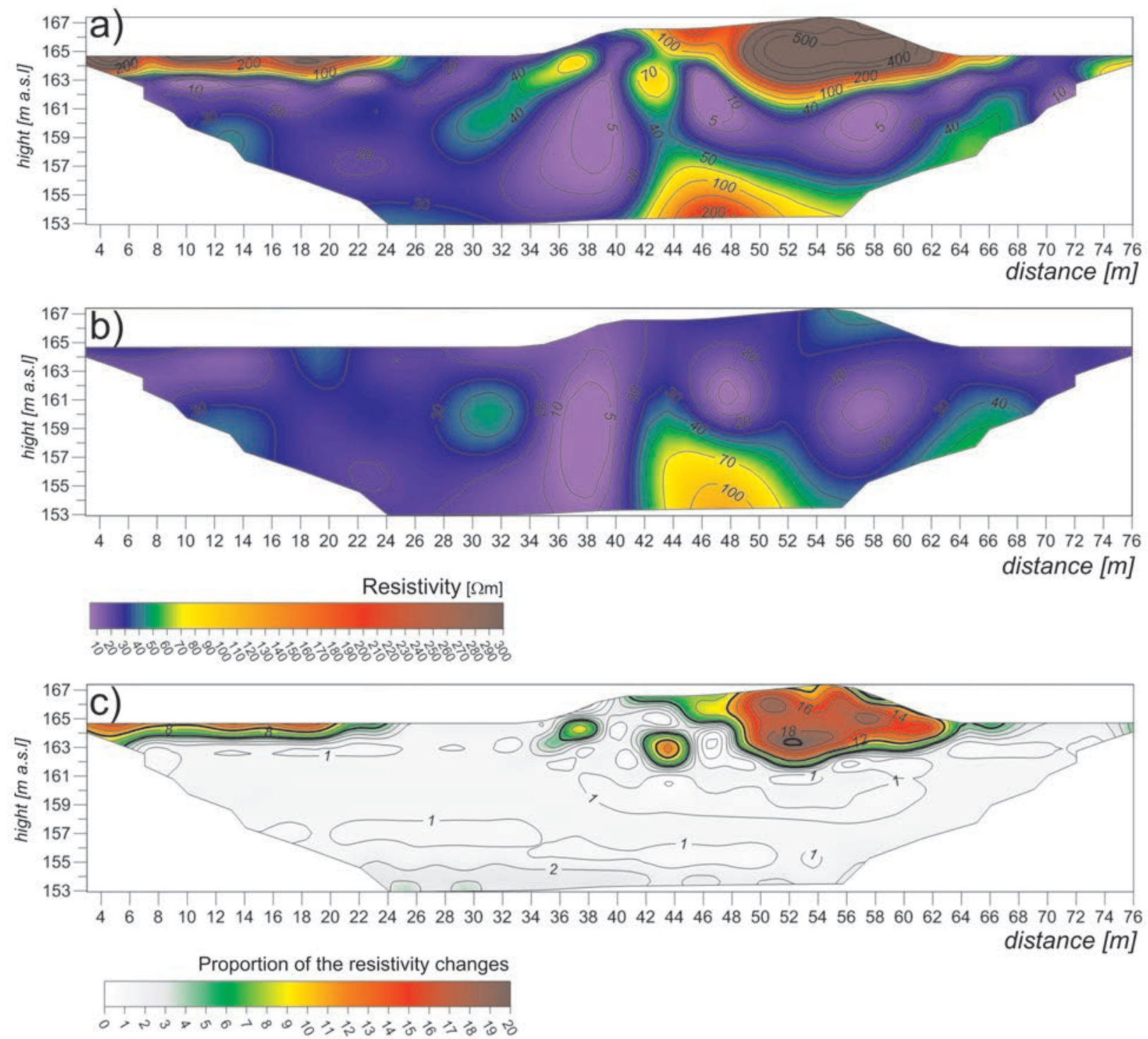

Fig. 8. Cross-section of differences between fig. 6 and fig. 7.

\section{RESULTS}

RES2Dinv program (Loke, 2012) was used to process the data received. There are clear contrasts in soils resistivity in the area covered by the ERT measurements:

- a complex of river sands interbedded by alluvial soils (silty clay and silt) with resistivities above $50 \Omega \mathrm{m}$,

- cohesive soils complex - Neogene clays and silts with low resistivities of 5 to $40 \Omega \mathrm{m}$,

- hydraulic fracture zone within the cohesive soils complex of resitivities from 40 to $70 \Omega \mathrm{m}$.

\section{Stage I}

ERT measurements allow to clearly identify the hydraulic fracture zone (layer IV - Fig. 6). Refers to profile 14, at the depth of bottom of foundation trench soils of low resistivity dominate - cohesive soils of very low permeability. The hydraulic fracture zone crosses the foundation depth in the
40-42 m of profile length. The value of resistivity are increased in this zone to $60-80 \mathrm{~W} \mathrm{~m}$ and contrasts to the cohesive soils $(5-40 \Omega \mathrm{m})$.

In the range of 30-32 $\mathrm{m}$ and $65-68 \mathrm{~m}$ of profile length there were also distinguished soils of be increased value of electrical resistivity. There are probably saturated sands. Their presence in the bottom of the foundation trench may cause some problems during the construction works.

\section{Stage II}

ERT measurements showed that diaphragm wall covered the entire embankment and cohesionless soils founded in the bottom of the trench (layer II and the surface layer of V -Fig. 6). The reduction of the electric resistivity in the area of hydraulic fracture zone, entire area of embankment and cohesionless soils in the bottom of the trench was noted as a results of clayey slurry injections (Fig. 7.).

Clayey diaphragm wall reduced anomaly IV at 30-32 m 

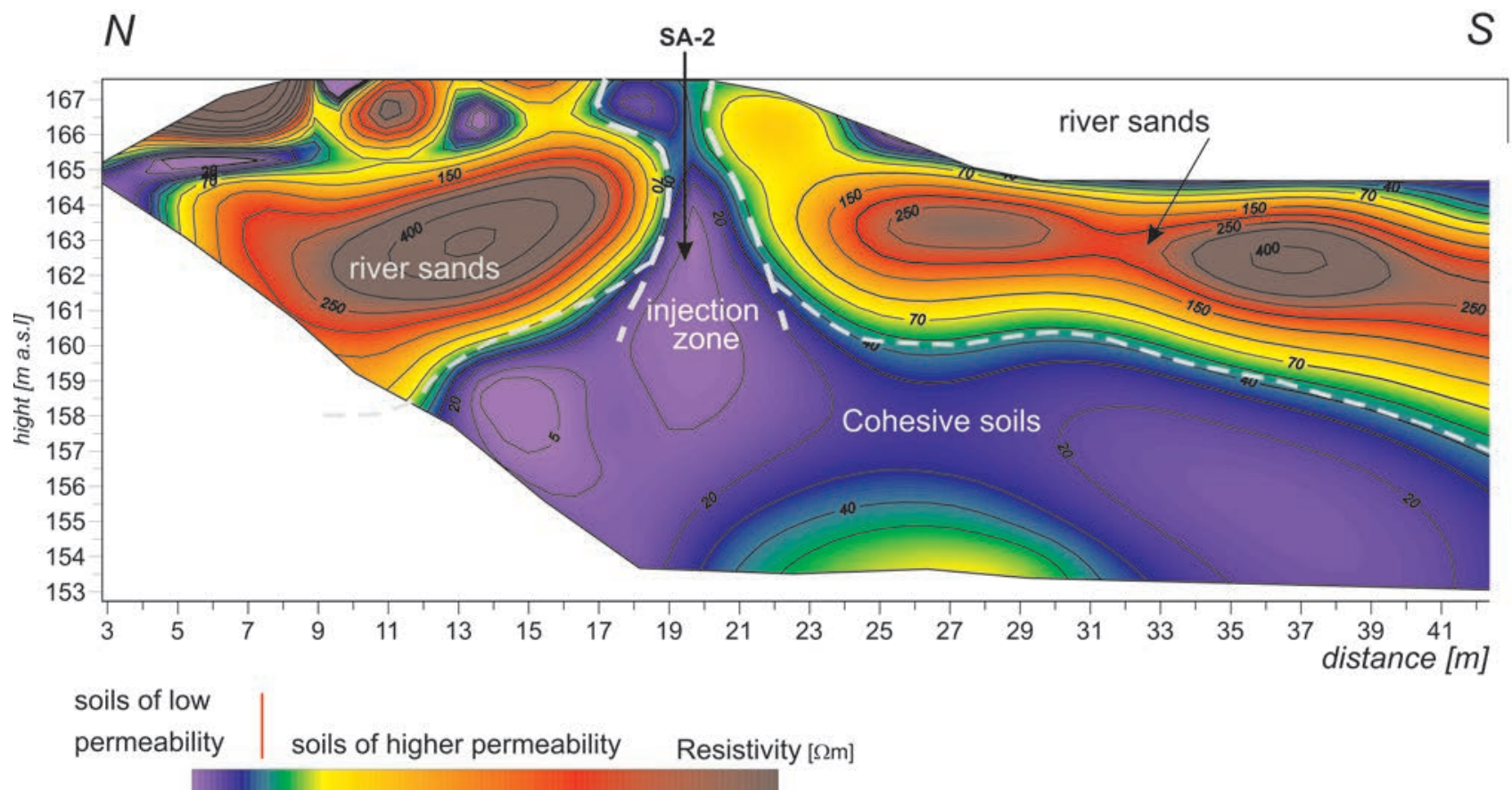

ㅍㅇㅇ क में

Fig. 9. Electrical resistivity cross-section- stage 2, profile 3.
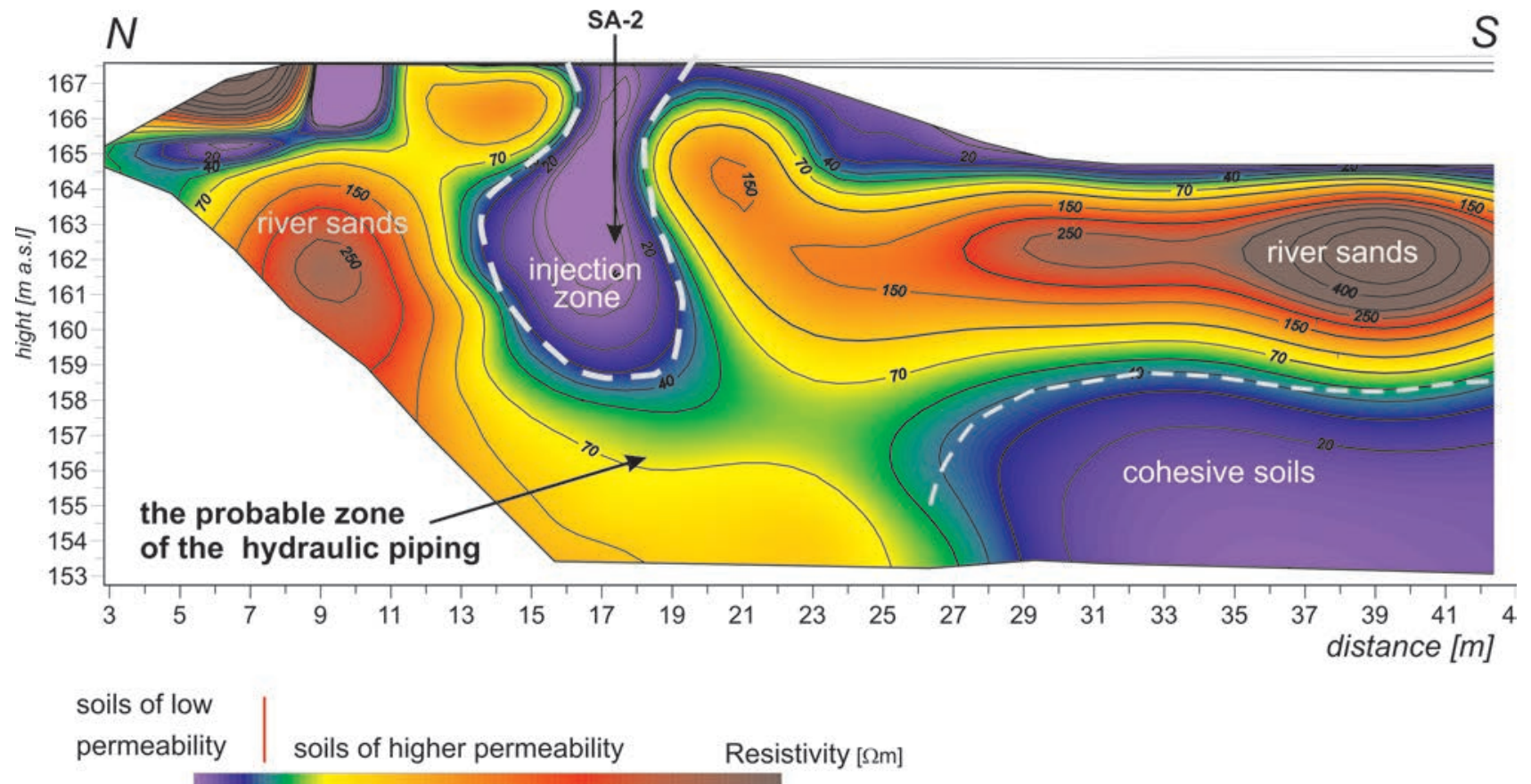

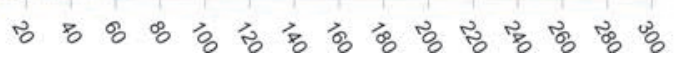

Fig. 10. Electrical resistivity cross-section- stage 2, profile 4 .

of profile length, but increased resistivity zone at the 65$68 \mathrm{~m}$ of profile length remained almost unchanged.

The comparison of the distribution of electrical resistivity for stage 1 and stage 2 , and resistivity decrease after injection works for selected profile is presented in Fig. 8. Red color marks the places where there was the greatest change in percentage value of resistivity, white color - where there is the smallest change.

The effect of clayey slurry injections is also noted in the other ERT profiles due to the contrast to the resistivity of the cohesionless soil. Significant decrease of electical resistivity is noted in the location of clay injetions (Figs 9, 10). 


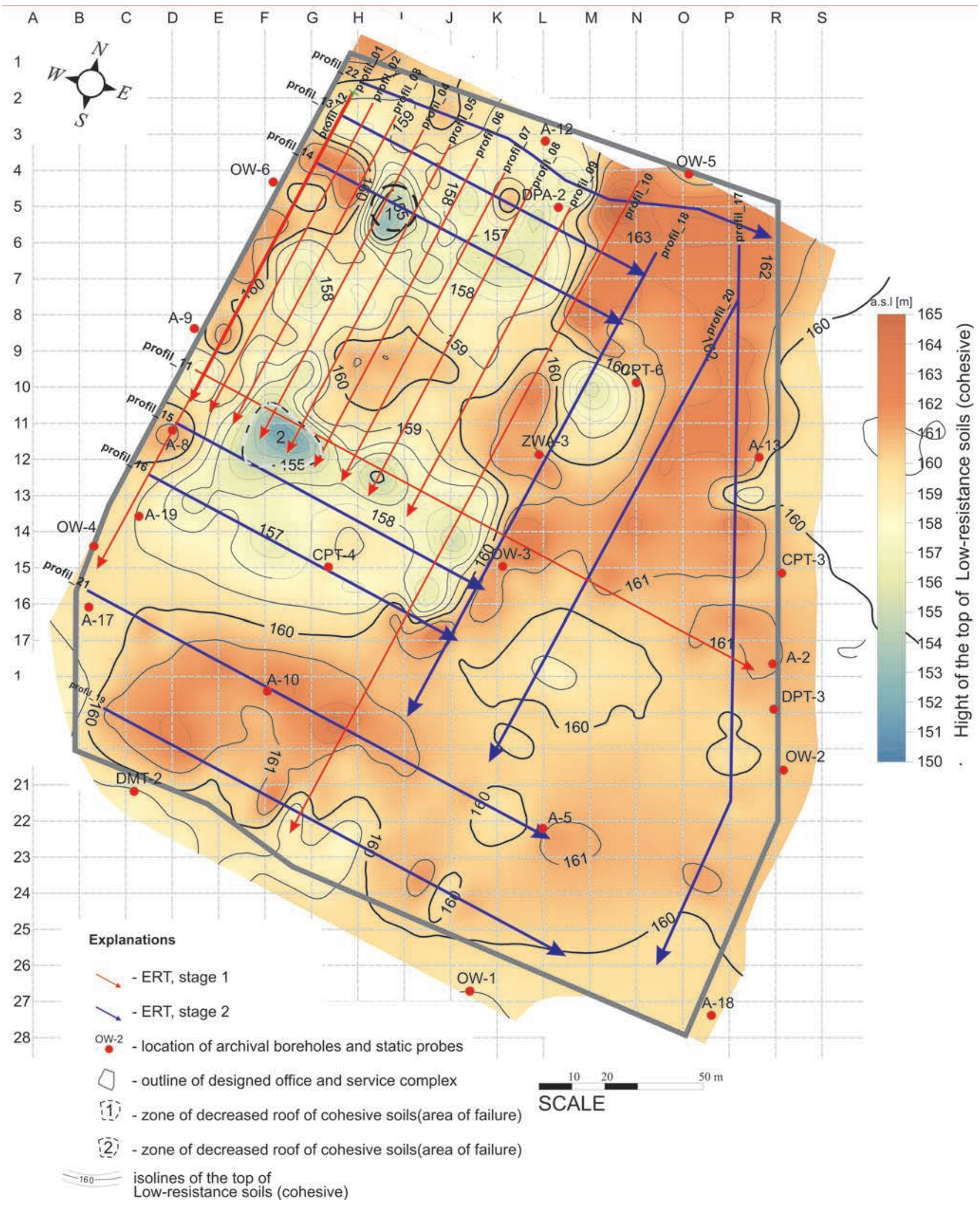

Fig. 11. Map of the roof of low-resistivity soils (cohesive) made on the basis of ERT cross-section and archival boreholes.

\section{The map of the roof of low-resistivity soil}

Interpretation of all the ERT profiles and analysis of boreholes and static probes allowed to prepare the map of the roof of low-resistivity sediments (Fig. 11). Low resistivity soil layer corresponds to the cohesive soils of very low permeability. This layer protects the trench from the confined aquifer. The depth of the roof of low-resistivity layer is variable and it's ranging from $152 \mathrm{~m}$ to $165 \mathrm{~m}$ above sea level. Two areas where the roof of low-resistivity sediments clearly 
decreases were highlighted in Fig. 11. In the area 1 the roof occurs at approximately $155 \mathrm{~m}$ above sea level - this is the place where the hydraulic fracture occurred and the water flowed to the trench. In the area 2 the roof is approximately $152 \mathrm{~m}$ above sea level, at this area a slight flow of water into the trench was observed, but it was managed to be controlled the local dewatering.

\section{CONCLUSIONS}

The resolution of presented methodology of ERT measurements was $2 \mathrm{~m}$ horizontally, while vertically it was depends on the depth and varies from $1 \mathrm{~m}$ (near the surface) to $2 \mathrm{~m}$ (at the bottom part of the cross-section).

Due to the accuracy of distribution in electrical resistivity even minor anomalies, slight variation of lithology, hydrogeological conditions, anthropogenic deposits or other non-documented effects of human activity can be detected. Thus more detailed and reliable description of geological structure and geological boundaries may be achieved.

The ERT method is relatively quick method that enabled the precise non-invasive identification of soil and rock layers in the areas of complicated geology, where the conventional direct invasive research methods could not guarantee the full recognition of soil-water conditions. The interpretation of the unexplored rock and soil mass between the boreholes may lead to the construction failure both at the stage of construction works (as in the presented example), but also making it even more dangerous - at the stage of use the completed building.

\section{REFERENCES}

Barski, M., Mieszkowski R., 2014. Upper Jurassic large-scale debris flow deposits in interbiohermal basins of the sponge megafacies in Poland - new insights, Neues Jahrbuch Fur Geologie Und Palaontologie-Abhandlungen Vol. 272/1, pp 47-59

Bogoslovsky, V.A., Ogilvy, A.A., 1977. Geophysical methods for the investigation of landslides. Geophysics 42, 562-571.

Brunet, P., Clément, R. , Bouvier Ch. , 2010. Monitoring soil water content and deficit using Electrical Resistivity, Tomography (ERT) - A case study in the Cevennes area, France Journal of Hydrology 380 (2010) 146-153. DOI: 10.1016/j.jhydrol. 2009.10.032

Cardarelli, E., Cercato, M., Di Filippo, G., 2007. Assessing foundation stability and soilstructure interaction through integrated geophysical techniques: a case history in

Rome (Italy). Near Surface Geophysics 5, 141-147. DOI: 10.3997/ 1873-0604.2006026

Chambers, J. E, Wilkinson, P. B., Weller, A. L., Meldrum, P. I., Ogilvy, R. D, Caunt, S., 2007. Mineshaft imaging using surface and crosshole $3 \mathrm{D}$ electrical resistivity tomography: A case history from the East Pennine Coalfield, UK, Journal of Applied Geophysics 62, pp 324-337. DOI: 10.1016/j.jappgeo. 2007.03.004

Daily, W., Ramirez, A. L., 2000. Electrical imaging of engineered hydraulic barriers. Geophysics 65(1):83-94Farooq, M., Kim, J.H., Park, S., Song, Y.S., 2007. Non-destructive evaluation of cementgrout by surface electrical resistivity method. Advanced Nondestructive Evaluation II 1, 599-604.

Foti, S., Lancellotta, R., 2003. Capabilities of seismic tests in soil characterization. In: Maugeri, M., Nova, R. (Eds.). Gotechnical analysis of seismic vulnerability ofmonuments and historical sites, pp. 83-98. Pàtron Editor, Italy.

Göktürkler, G., Balk Aya, Ç. \& Erhan, Z., 2008. Geophysical investigation of a landslide: The Alt nda landslide Site, zmir (western Turkey). Journal of Applied Geophysics, 65 (2): 84-96. DOI: 10.1016/j.jappgeo.2008.05.008

Griffiths, D. H., Barker, R. D., 1993. Two-dimensional resistivity imaging and modelling in areas of complex geology. Journal of Applied Geopgysics, no. 29, pp. 211-226.

Hack, R., 2000. Geophysics for slope stability. Surveys in Geophysics $21,423-448$.

Jol, H.M. (Ed.), 2009. Ground Penetrating Radar: Theory and Application, 1st ed., Elsevier.

Kirsch, R., (Ed.), 2009. Groundwater Geophisics, A Tool for Hydro-geology, 2en ed., Springer.

Keller, G.V. \& Frischknecht F.C., 1966. Electrical methods in geophysical prospecting. Pergamon Press Inc., Oxford.

Kowalczyk S., Mieszkowski, 2011. Określanie spagu gruntów organicznych metodami geofizycznymi na przykładzie dwóch poligonów badawczych na Niżu polskim, Biuletyn Państwowego Instytutu Geologicznego Tom 446/1 r. 2011, str. 191198 Loke, M. H., 2012. Tutorial: 2-D and 3-D electrical imagining surveys, Geotomo Software, Malaysia.

Martínez-Pagán, P., Gómez-Ortiz, D., Martín-Crespo, T., Manteca, J.I. , Rosique, M., 2013. The electrical resistivity tomography method in the detection of shallow mining cavities. A case study on the Victoria Cave, Cartagena (SE Spain), Engineering Geology 156, 1-10. DOI: 10.1016/j.enggeo.2013.01.013

Ramirez, A, Daily, W, Labrecque, D, Owen, E, Chesnut, D.,1993. Monitoring an underground steam injection process using electrical resistance tomography. Water Resour Res 29(1): 73-87Schueremans, L., Van Rickstal, F., Verderickx, K., Van Gemert, D., 2003. Evaluation of masonry consolidation by geo-electrical relative difference resistivity mapping.RILEM Materials \& Structures 36, 46-50.

Santarato, G., Ranieri, G., Occhi, M., Morelli, G., Fischanger, F., Gualerzi, D., 2011. Three-dimensional Electrical Resistivity Tomography to control the injection of expanding resins for the treatment and stabilization of foundation soils, Engineering Geology 119 , 18-30 pp. DOI: 10.1016/J.ENGGEO.2011. 01.009

Sharma, P.V., 2002. Environmental and engineering geophysics. Cambridge University Press, Cambridge, UK. 475 pp.

Slater, L., Binley, A., Daily, W., Johnson, R., 2000. Cross-hole electrical imaging of a controlled saline tracer injection. Journal of Applied Geophysics 44, 85-102. 